\title{
Customer Service Quality Practice in District Co-Operative Bank - with Reference to Thiruvananthapuram District Cooperative Bank
}

\author{
Sandhya.S, Viji Vijayan, Hari Sundar Govindaraman
}

\begin{abstract}
As the entry of sophisticated technology has paved way for greater developments in every field including the banking sector, the banking sector too is characterized by rapid change and increasingly sophisticated customers. It has become very important that banks in India determine the service quality factors, which are pertinent to the customer's selection process. With the advent of international banking, the trend towards larger bank holding companies, and innovations in the marketplace, the customers have greater and greater difficulty in selecting one institution from another (Choudhury, K. (2018)). Therefore the current problem for the banking industry in India is to determine the dimensionality of customer-perceived service quality. If service quality dimensions are identified, the service managers should be able to improve the delivery of customer perceived quality during the service process and have greater control over the overall outcome. A better understanding of the effects of service quality and customer satisfaction on service loyalty can help academics in the development of a model of service marketing. It can also provide practitioners with indications as to where best to devote marketing attention and scarce corporate resources.
\end{abstract}

Keywords : Servqual, customer loyalty, service marketing, Cooperative bank.

\section{INTRODUCTION}

In the present competitive Indian banking context, characterized by rapid change and increasingly sophisticated customers, it has become very important that banks in India determine the service quality factors, which are pertinent to the customer's selection process. With the advent of international banking, the trend towards larger bank holding companies, and innovations in the marketplace, the customers have greater and greater difficulty in selecting one institution from another (Choudhury, K. (2008)). Therefore the current problem for the banking industry in India is to determine the dimensionality of customer- perceived service quality. If service quality dimensions are identified, the service managers should be able to improve the delivery of customer perceived quality during the service process and

\footnotetext{
Revised Manuscript Received on December 05, 2019.

* Correspondence Author

Sandhya.S*, Research scholar, VTU, Bengaluru, India.

Viji Vijayan, Research scholar, KUFOS, Bengaluru, India.

Dr. Hari Sundar Govindaraman, Associate Professor, Chinmaya Vishwavidyapeeth, Kochi, India.
}

have greater control over the overall outcome.

\section{SERVICES QUALITY AND BANKING}

Today it is essential to corporate profitability and survival. The link between service quality and customer satisfaction has been submitted to intense scrutiny by leading service quality researchers; as well as the links between quality, customer satisfaction, customer retention and profitability(Parasuraman, A., Berry, L. L. and Zeithaml, V. A. 1985). The connection between service quality and corporate profitability is now seen to depend on high levels of customer satisfaction, the successful targeting of "quality" customers and the retention of those customers of the banking sector(Prabhakaran, S. and Satya, S. 2013).

\section{REVIEW OF LITERATURE}

Service quality has been viewed as a significant issue in the banking industry by Stafford (1994).Since financial services are generally undifferentiated products, it becomes imperative for banks to strive for improved service quality if they want to distinguish themselves from the competition. Positive relationship between high levels of service quality and improved financial performance has been established by Benter (1990).

In the current marketing literature, much attention on the issue of service quality as related to customerse ${ }^{\text {ee }}$ attitudes towards services has focused on the relationship between customer expectations of a service and their perceptions of the quality of provision. This relationship known as perceived service quality was first introduced by Gronroos (1982). In developing SERVQUAL, Parasuraman et. al (1988) recast the 10 determinants into five principal dimensions: tangibles, reliability, responsiveness, assurance and empathy. Following their works, other researchers have adopted this model for measuring service quality in various service industries. Application of this model to measure the quality of service in the banking industry was conducted by Prabhakaran (2013).

Banking can consider the business that really appreciates the value of building long-term relationships with customers. With the range of services offered by banks - brokerage, home equity, mortgage refinance, credit cards, and debit cards, among others successful banks want to serve 


\section{Customer Service Quality Practice in District Co-Operative Bank - with Reference to Thiruvananthapuram District Cooperative Bank}

customers by offering services and products that meet both personal and business banking needs.

In today's highly competitive, increasingly consolidated world, offering personalized and differentiating services can be critical to a bank's success.

The most popular view of customer satisfaction in academia is that customer satisfaction is the judgment borne out of the comparison of pre-purchase expectations with post purchase evaluation of the product or service experience (Oliver, 1997).Strong linkages have been apparent between service quality dimensions (for example fast responses to enquiries) and overall customer satisfaction (Anderson1998). But much debate arises from whether customer satisfaction is an antecedent of service quality judgments (Bitner, 1990; Parasuraman, et al, 1985) or the other way round.

\section{NEED FOR THE STUDY}

After carefully analysing various research studies conducted so far using the SERVQUAL model, the Researchers realise that many research works have been carried in different service industries such as telecommunication, education, restaurants, banking, health care, etc, but limited empirical study has been conducted using the SERVQUAL model to assess service quality in Co-operative Banks.

\section{AIM OF THE STUDY}

Customer values, beliefs, customs and behaviour are constantly changing. Customers are becoming more critical and selective of the quality of service. Service quality has been the subject of considerable interest by both practitioners and researchers in recent years. An important reason for the interest in service quality by practitioners results from the belief that this has a beneficial effect on bottom-line performance for the firm. However, practitioners often tend to use the terms service quality and customer satisfaction interchangeably. Among academics the satisfaction construct is recognized as being distinct and has developed along fairly independent lines from service quality. The concepts of service quality, customer satisfaction and service loyalty are related to each other. A better understanding of the effects of service quality and customer satisfaction on service loyalty can help academics in the development of a model of service marketing. It can also provide practitioners with indications as to where best to devote marketing attention and scarce corporate resources.

\section{STATEMENT OF THE PROBLEM}

Recognition of service quality as a competitive weapon is relatively a recent phenomenon in the Indian Banking sector. Prior to the liberalization era the banking sector in India was operating in a protected environment and was dominated by nationalized banks. Banks at that time did not feel the need to pay attention to service quality issues and they assigned very low priority to identification and satisfaction of customer needs. The need of the hour in the Indian banking sector is to build up competitiveness through enhanced service quality, thus making the banks more market oriented and provide more loans to the customers as they want to improve their standard of living.

Moreover, investigating the influence of the dimensions of service quality on customers behavioural intentions should provide a better understanding of the customer satisfaction and also help to specify measure, control and improve customer perceived service quality. Hence, to gain and sustain competitive advantages in the fast changing Co-operative banks in India, it is crucial for banks to understand in-depth what customers perceive to be the key dimensions of service quality and what impacts the identified dimensions have on customer's behavioural intentions.

Despite many fundamental banking reformations, still Cooperative banks are lagging behind on many fronts compared with commercial banks. That results for the Cooperative banks relative weakness in service quality and product quality as delivered to domestic customers.

This study is an attempt to study about the various service quality dimensions of banking. The present research pays its attention on Cooperative banks, expected and perceived quality on banking services and the satisfaction level of the particular service of the bank. The credit facility is the ultimate determinant of Quality of Service and decides the motivated loyal customers of a Cooperative bank. Since there are seven Taluks and 27 branches in Coimbatore district, the study will help for enhancing their service quality.

\section{RESEARCH OBJECTIVES}

1. To analyze the social and economic characteristics of the respondents in the study area;

2. To analyze the service quality of Coimbatore district Cooperative Banks in Coimbatore;

3. To analyze the influence of Service Quality on Customer Satisfaction Coimbatore district Cooperative Banks in Coimbatore;

4. To find out the relationship between the dimensions of Banking Service Quality and their influence on the customer satisfaction factor and

5. Offer suggestions based on the findings of the study.

\section{SAMPLING}

The proposed research is basically a survey to assess the service provided by of Thiruvananthapuram District Cooperative Bank at Thiruvananthapuram Kerala. For this research, the head office and its branches were selected. The units of analysis for this study were customers of Co-operative banks in Thiruvananthapuram District who had contacts with the banks on a regular basis over last few months and who visited the bank premises frequently for transactions. The sampling procedure to be used for the study will be Non- Probability sampling.

Published By:

Blue Eyes Intelligence Engineering 
A convenience sampling technique was employed on the basis of pre-specified criteria mentioned as above to select 145 sample respondents' urban areas of Thiruvananthapuram district. Structured Questionnaire was used to collect primary data, consisting of 31questions with 5 point scale response varied from Highly Dissatisfied to Highly Satisfied and Strongly Agree to Strongly Disagree apart from the personal variables.

\section{ANALYSIS-SOCIO-ECONOMICAL VARIABLES}

The total number of respondents was 145 in which 33.3 percent of the respondents were of the age $36-45,31.1$ percent of the respondents were of the age $25-35,20$ percent of the respondents were of the age 46 and above, 15.6 percent of the respondents were of the age less than twenty five years.

Among the respondents of $145,33.3$ percent of the respondents were having a qualification under graduation, 31.1 percent of the respondents were having a qualification higher secondary, 15.6 percent of the respondents were having a qualification post graduation, 13.3 percent of the respondents were having a qualification SSLC and 6.7 percent of the respondents were having a qualification no education.

Among the respondents of 145,35.6 percent of the respondents are self-employed, 22.2 percent of the respondents are retired, 15.6 percent of the respondents are private employed, 15.6 percent of the respondents are house wife and 11.1percent of the respondents are government employed.

Table - 1: Factor which Customer considered most
important for opening an Account
\begin{tabular}{|l|c|c|}
\hline & Frequency & Percent \\
\hline Location & 26 & 17.9 \\
\hline Deposit interest rate & 16 & 11 \\
\hline Loan interest rate & 21 & 14.5 \\
\hline Convenient business hours & 13 & 9.0 \\
\hline Employee behaviour & 10 & 6.9 \\
\hline Facilities and amenities & 16 & 11 \\
\hline Security norms & 20 & 13.8 \\
\hline Good service & 13 & 9.0 \\
\hline Advance technology & 10 & 6.9 \\
\hline Total & 145 & 100 \\
\hline
\end{tabular}

Out of 145 respondents, 17.9percent of the respondents consider Location, 14.5percent of the respondents consider loan interest rate, 13.8percent of the respondents consider security norms, 11percent of the respondents consider facilities and amenities, 11 percent of the respondents deposit interest rate, 9percent of the respondents consider good service, 9percent of the respondents consider convenient business hours, 6.9percent of the respondents consider advance technology and employee behaviour respectively.

\section{Mean Score Comparison on Service Quality Expectations} and Perception
Table - 2: Tangibility

\begin{tabular}{|l|c|c|c|}
\hline \multicolumn{1}{|c|}{ Items } & Expectations & Perceptions & \multirow{2}{*}{ Gap } \\
\cline { 2 - 3 } & $\begin{array}{c}\text { Mean Score } \\
(\text { SD })\end{array}$ & $\begin{array}{c}\text { Mean Score } \\
(\text { SD })\end{array}$ & \\
\hline $\begin{array}{l}\text { Bank has modern looking } \\
\text { equipment. }\end{array}$ & $3.147(1.231)$ & $\begin{array}{c}1.666 \\
(1.085)\end{array}$ & 1.481 \\
\hline $\begin{array}{l}\text { Physical facilities are visually } \\
\text { appealing. }\end{array}$ & $3.297(1.266)$ & $\begin{array}{c}2.915 \\
(1.211)\end{array}$ & 0.382 \\
\hline $\begin{array}{l}\text { Employees are neat in } \\
\text { appearance. }\end{array}$ & $3.581(0.933)$ & $\begin{array}{c}2.894 \\
(1.092)\end{array}$ & 0.686 \\
\hline $\begin{array}{l}\text { Pamphlets or statements are } \\
\text { visually appealing }\end{array}$ & $4.655(0.562)$ & $\begin{array}{c}1.747 \\
(1.058)\end{array}$ & 2.908 \\
\hline Mean Score & $3.670(0.998)$ & $\begin{array}{c}2.305 \\
(1.112)\end{array}$ & 1.364 \\
\hline
\end{tabular}

The difference gap between the expectation and perception of the customers in tangibility dimension is high in the variable of the pamphlets or statements are visually appealing then the modern looking equipments with the mean gap values of 2.908and 1.4.81 respectively. The next highest difference is seen in the appearance of the employees and the last variable gap is the appealing physical facilities with mean values of 0.686 and 0.382 respectively.

The customers agree with the tangibility measure in their expectation with a mean of 3.670 whereas the Perception of customer neither agree nor disagree with the bank with a mean score of 2.305. The overall difference has a mean value of 1.364 which is considerably more between the expectation and perception.

Table - 3: Reliability

\begin{tabular}{|c|c|c|c|}
\hline \multirow{2}{*}{ Items } & Expectations & Perceptions & \multirow{2}{*}{ Gap } \\
\hline & $\begin{array}{l}\text { Mean Score } \\
\text { (SD) }\end{array}$ & $\begin{array}{l}\text { Mean Score } \\
\text { (SD) }\end{array}$ & \\
\hline $\begin{array}{l}\text { Bank promise to do something } \\
\text { time, they do. }\end{array}$ & $\begin{array}{c}4.731 \\
(0.443)\end{array}$ & $\begin{array}{c}2.272 \\
(0.980)\end{array}$ & 2.458 \\
\hline $\begin{array}{l}\text { Banks show sincere interest in } \\
\text { solving customer problem. }\end{array}$ & $\begin{array}{c}3.920 \\
(0.845)\end{array}$ & $\begin{array}{c}2.371 \\
(0.947)\end{array}$ & 1.549 \\
\hline $\begin{array}{l}\text { Banks perform service right } \\
\text { the first time. }\end{array}$ & $\begin{array}{c}3.771 \\
(0.891)\end{array}$ & $\begin{array}{c}2.690 \\
(1.129)\end{array}$ & 1.081 \\
\hline $\begin{array}{l}\text { Banks provide the service at } \\
\text { time they promise to do so. }\end{array}$ & $\begin{array}{c}4.060 \\
(0.840)\end{array}$ & $\begin{array}{c}2.756 \\
(1.057)\end{array}$ & 1.304 \\
\hline Bank has error free records. & $\begin{array}{l}4.020 \\
(0.926)\end{array}$ & $\begin{array}{l}2.120 \\
(0.797)\end{array}$ & 1.899 \\
\hline Mean Score & $\begin{array}{l}4.100 \\
(0.789)\end{array}$ & $\begin{array}{c}2.442 \\
(0.982)\end{array}$ & 1.658 \\
\hline
\end{tabular}

The difference between the expectation and the perception of the reliability dimensions with high difference in the promise kept by the bank with mean values 2.458 , then next highest difference comes in error free records with a mean value of 1.899. Then the mean value of 1.549 , shows interest of solving customer problems, then the difference is seen service in time as promised by the bank with a mean value of 1.304 , and the last difference is seen in right service at right time with a mean value 1.081 . 


\section{Customer Service Quality Practice in District Co-Operative Bank - with Reference to Thiruvananthapuram}

District Cooperative Bank

Table - 4: Responsiveness

\begin{tabular}{|l|c|c|c|}
\hline \multirow{2}{*}{ Items } & Expectations & Perceptions & \multirow{2}{*}{ Gap } \\
\cline { 2 - 3 } & $\begin{array}{c}\text { Mean Score } \\
\text { (SD) }\end{array}$ & $\begin{array}{c}\text { Mean Score } \\
\text { (SD) }\end{array}$ & \\
\hline $\begin{array}{l}\text { Customers are said exactly } \\
\text { when services will perform. }\end{array}$ & $\begin{array}{c}3.143 \\
(1.422)\end{array}$ & $\begin{array}{c}2.973 \\
(1.114)\end{array}$ & 0.170 \\
\hline $\begin{array}{l}\text { Banks gives prompt service to } \\
\text { customers. }\end{array}$ & $\begin{array}{c}3.013 \\
(1.122)\end{array}$ & $\begin{array}{c}2.709 \\
(1.213)\end{array}$ & 0.304 \\
\hline $\begin{array}{l}\text { Bank employees will always } \\
\text { willing help customer. }\end{array}$ & $\begin{array}{c}3.062 \\
(1.231)\end{array}$ & $\begin{array}{c}2.653 \\
(0.934)\end{array}$ & 0.409 \\
\hline $\begin{array}{l}\text { Bank employees quick } \\
\text { respond to customer's } \\
\text { requests. }\end{array}$ & $\begin{array}{c}4.496 \\
(0.543)\end{array}$ & $\begin{array}{c}2.789 \\
(1.100)\end{array}$ & \multirow{2}{*}{1.706} \\
\hline Mean Score & $\begin{array}{c}3.429 \\
(1.080)\end{array}$ & $\begin{array}{c}2.781 \\
(1.090)\end{array}$ & 0.647 \\
\hline
\end{tabular}

Regarding the dimension of responsiveness, the difference gap between the expectation and perception of the customers are high with the employees quick respond to customer's requests with a mean value of 1.706 , then the employees are willing to help customer with a difference of 0.409 , the next highest difference is seen in the prompt service to customers with 0.304 , the last is that the customers are said exactly when services will be performed with a difference of 0.382 .

Table - 5: Assurance

\begin{tabular}{|c|c|c|c|}
\hline \multirow{2}{*}{ Items } & Expectations & Perceptions & \multirow{2}{*}{ Gap } \\
\hline & $\begin{array}{l}\text { Mean Score } \\
\text { (SD) }\end{array}$ & $\begin{array}{c}\text { Mean Score } \\
\text { (SD) }\end{array}$ & \\
\hline $\begin{array}{l}\text { Employee's behaviour will } \\
\text { instil confidence in customers. }\end{array}$ & $\begin{array}{c}3.843 \\
(1.093)\end{array}$ & $\begin{array}{c}2.279 \\
(0.862)\end{array}$ & 1.563 \\
\hline $\begin{array}{l}\text { Customers would feel safe in } \\
\text { transactions. }\end{array}$ & $\begin{array}{c}3.306 \\
(1.481)\end{array}$ & $\begin{array}{c}2.275 \\
(0.987)\end{array}$ & 1.030 \\
\hline $\begin{array}{l}\begin{array}{l}\text { Employees } \\
\text { consistently }\end{array} \text { courteous } \\
\text { customers. }\end{array}$ & $\begin{array}{l}3.830 \\
(0.941)\end{array}$ & $\begin{array}{c}2.715 \\
(1.150)\end{array}$ & 1.114 \\
\hline $\begin{array}{l}\text { Employees would have the } \\
\text { knowledge to answer } \\
\text { customer's questions. }\end{array}$ & $\begin{array}{c}3.416 \\
(1.193)\end{array}$ & $\begin{array}{c}2.894 \\
(1.092)\end{array}$ & 0.521 \\
\hline Mean Score & $\begin{array}{c}3.598 \\
(1.177)\end{array}$ & $\begin{array}{c}2.541 \\
(1.023)\end{array}$ & 1.057 \\
\hline
\end{tabular}

The gap difference in assurance dimension the expectation and perception of the customers is highest on employee's behaviour would instill confidence in customers with a value of 1.563 , then next difference is seen with employees would be consistently courteous with customers with a mean value of 1.114, whereas next difference is seen with customers would feel safe in transactions with a mean value of 1.03. Finally the least difference is seen with employees would have the knowledge to answer customer's questions with a value of 0.52 .

Table - 6: Empathy

\begin{tabular}{|c|c|c|c|}
\hline \multirow{2}{*}{ Items } & Expectations & Perceptions & \multirow{2}{*}{ Gap } \\
\hline & $\begin{array}{c}\text { Mean Score } \\
\text { (SD) }\end{array}$ & $\begin{array}{c}\text { Mean Score } \\
\text { (SD) }\end{array}$ & \\
\hline $\begin{array}{l}\text { Banks give customers } \\
\text { individual attention. }\end{array}$ & $\begin{array}{c}3.496 \\
(1.202)\end{array}$ & $\begin{array}{c}2.454 \\
(0.955)\end{array}$ & 1.042 \\
\hline $\begin{array}{l}\text { Banks has convenient } \\
\text { operating hours. }\end{array}$ & $\begin{array}{c}3.250 \\
(1.476)\end{array}$ & $\begin{array}{c}2.556 \\
(1.081)\end{array}$ & 0.694 \\
\hline
\end{tabular}

\begin{tabular}{|l|c|c|c|}
\hline $\begin{array}{l}\text { Banks has employees who give } \\
\text { customers personal service. }\end{array}$ & $\begin{array}{c}3.695 \\
(1.052)\end{array}$ & $\begin{array}{c}2.915 \\
(1.211)\end{array}$ & 0.780 \\
\hline $\begin{array}{l}\text { Banks has their customer's } \\
\text { best interest at heart. }\end{array}$ & $\begin{array}{c}3.597 \\
(1.404)\end{array}$ & $\begin{array}{c}1.448 \\
(0.924)\end{array}$ & 2.148 \\
\hline $\begin{array}{l}\text { Banks employees understand } \\
\text { the specific needs of their } \\
\text { customers. }\end{array}$ & $\begin{array}{c}4.302 \\
(0.686)\end{array}$ & $\begin{array}{c}1.413 \\
(0.896)\end{array}$ & 2.888 \\
\hline Mean Score & $\begin{array}{c}3.668 \\
(1.164)\end{array}$ & $\begin{array}{c}2.157 \\
(1.013)\end{array}$ & 1.510 \\
\hline
\end{tabular}

The gap difference of empathy dimension towards expectation and perception is large at the banksemployees understand the specific needs of their customers and Banks have their customer's best interest at heart with mean values of 2.888 and 2.148 respectively. The banks give customers individual attentionwith a mean value of 1.042. Finally least difference are seen with the banks has employees who give customers personal service and banks haveconvenient operating hours with a mean difference value of 0.780 and 0.694 respectively.

\section{FINDINGS}

The highest services quality gap between expectation and perception with regard to tangibility factors lies on promotional material like pamphlets or statement which shows that the visually appealing material for promotion of bank services lack behind from the perception of customers, overall services quality gap in tangibility factor is high.

The next highest services quality gap is seen between expectation and perception regarding reliability factors, the variable like the bank promise to do something in time the error force records and bank officials show interest in solving the problems in time are lack behind from the expectation of the customers. The overall services quality gap is reliability factors is high

Regarding responsiveness factor, highest gap between the expectation and Perception, and Perception, the variable like the bank employee's quick response to customer request and they always willing to help customer are lack behind the customer expectation .The overall gap mean values shows that quality gap responsiveness factor is also high.

The overall mean score values on the reliability factors for the expectation of customers is 4.100 , which shows that the customer have high level of expectation whereas the customer perception on reliability factor is moderate since the Perception mean value is 2.442 . The overall difference value is 1.658 .

The gap difference of service quality between expectation and Perception in reliability is higher than empathy, whereas the tangibles are higher than the variables of assurance and responsiveness. The overall mean score of the gap difference between the service quality expectation and customer's perception shows large differentiated value of 1.2462 


\section{SUGGESTIONS}

In the present competitive environment, Cooperative Banks need to retain existing high-value customers to remain competitive. The research results proved that there is some factors influence customer in Coimbatore District Cooperative Bank is not satisfied. Marketing manager should seek to improve the area where customer is not satisfied to improve customer retention. The research findings clearly show that the drives towards ease of banking operation and convenience to customer's orientation are favored by the customer. Therefore, banks should find alternative strategic routes to improve service delivery either human-based or technology-based.

Bank customers' attitudes towards the human resource related services and subsequent level of satisfaction will impact on bank switching more than when the same service delivery is made through automation. More importantly, they are greatly linked with the customers' perceptions of how these bank services are delivered to them. These perceptual outcomes will, in turn, affect the level of bank customer satisfaction ratings, retention and switching rates.

\section{CONCLUSION}

The link between service delivery and customer satisfaction is patently visible in the study results. The financial institutions should continue to find effective ways to systematically measure and manage customer sustainable satisfaction and retention. Therefore the Customer care and customer retention programmes should take into consideration that the increased "push" towards the provision of convenient, easy and fast banking services is closely associated with the human and technology based delivery processes..

\section{REFERENCES}

1. Anderson et al. (1998) Multivariate Data Analysis. 5th ed. London: Upper Saddle River.

2. Bitner, M. (1990) Evaluating service encounters: the effects of physical surroundings and employee responses. Journal of Marketing. 54(2), 69.

3. Choudhury, K. (2018) Service Quality: insights from the Indian Banking scenario. AustralasianMarketing Journal.16(1), 48-61.

4. Gronroos, C. (2016) Service Management and Marketing: A Customer Relationship Management Approach. 2nd ed. West Sussex: John Wiley \& Sons, Ltd.

5. Oliver, R. (1980) A cognitive model of the Antecedents and consequences of satisfaction decisions. Journal of Marketing Research. 17(4), 460.

6. Parasuraman, A., Berry, L. L. and Zeithaml, V. A. (1985) A ConceptualModel of Service Quality and Its Implications for Future Research. Journal of marketing. (4), 41.

7. Parasuraman, A., Berry, L. L. and Zeithaml, V. A. (1988) SERVQUAL: A multiple-item scale for measuring consumer perceptions of service quality. Journal of Retailing.(1), 12.

8. Prabhakaran, S. and Satya, S. (2013) An insight into Service Attributes in Banking Sector. Journal of Services Research. 3(1), 157-169.

9. Stafford, M.R. (1994), "How Customers Perceive Service Quality", Journal of Retail Banking, 17 (2), Summer.

10. Zeithaml, V. A., Wilson, A. and Bitner,M. J. (2008) Services Marketing. 4th ed. New Delhi: TheMcGraw-Hill Companies.

\section{AUTHORS PROFILE}

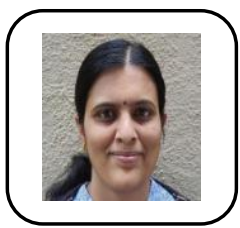

Ms. S. Sandhya, is Currently working as Project Manager in Honeywell Ltd at Bengaluru, Sandhya.S is a post graduate in Mechanical Engineering and is currently pursuing her Doctoral research in Visweswarayya Technical University, Karnataka. She has published and presented her research works at various conferences in India.

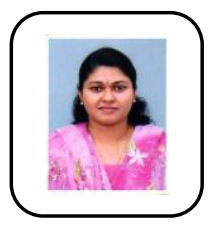

Ms.Viji Vijayan, is a MBA graduate from University of Kerala and is currently pursuing her Ph.D in Management from Kerala University of Fisheries and Ocean Studies (KUFOS) Kochi. She has published several research papers in reputed conferences and has also published many papers in reputed journals.

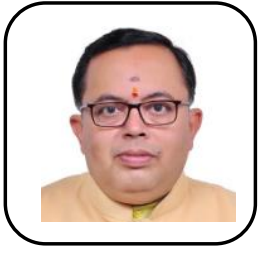

Dr. Hari Sunder, is Currently working as Associate Professor in Chinmaya Vishwavidyapeeth Kerala, Dr. Sundar has completed his Post Doctoral research in Management and hi areas of research are Marketing, Indian epics and case based teaching. He has published and presented several research papers to his credit. He has also won several awards in various conferences for best research presentations. 